\title{
Who is even studying journalism to become a journalist?
}

\author{
Prandner, Dimitri ${ }^{\mathrm{a}}$ and Moosbrugger, Robert $^{\mathrm{a}}$
}

${ }^{\mathrm{a}}$ Department for empirical Social Research, Johannes Kepler University Linz, Austria.

\begin{abstract}
The paper addresses the question why people are entering training programs which disseminate knowledge necessary for becoming part of the journalistic profession and how these motives go along with the intention to become a member of the profession. Therefore it draws on data collected among students in journalism related programs in Austria in $2015(n=352)$ and tests the linkage between socioeconomic background of the students, their motives for entering a program and how these affect the intention to work in the field of journalism. Factor analysis allowed the identification of four main motives: political and social agency; employment driven; social benefits; and calling/talent. Results show that a) motives for entering a program differ according to the socioeconomic background of the respondents. And b) the intention to work in the field is higher if motives tied to the ideas of agency and calling are reported and lower if employment driven motives are predominant. This leads to the conclusion that the motivation of students to join the journalistic profession is deeply related to believes and normative aspirations of individuals.
\end{abstract}

Keywords: journalism; higher education; profession; motivation. 


\section{Journalism as profession}

The two most general ideas underlying professionalism are the belief that certain work is so specialized as to be inaccessible to those lacking the required training and experience and the belief that it cannot be standardized (Freidson 2001, p. 17).

Freidson (2001) identifies professionalism as a specific form of social coordination. A profession draws on "a body of knowledge and skills ... based on abstract theories"; an "occupationally controlled labor market requiring training credentials"; as well as "an occupationally controlled training program .... associated with 'higher learning'” and shared codes of conducts (Freidson 2001, p. 180). What makes belonging to a profession so appealing is the image and prestige associated with the members of the collective (Evetts, 2011). This paper addresses the question why people are entering training programs which disseminate knowledge necessary for becoming part of the journalistic profession and how these motives go along with the intention to become a member of the profession. According to Hanusch et al. (2016, p. 102) understanding why students choose journalism, and what career expectations they hold, is important not only for educators but also for wider society and public debates about the future of journalism and the value of tertiary journalism education.

\subsection{Journalism and Journalism Education in Austria}

The case study in this paper is tied to Austria, a western democracy that is renowned for its highly concentrated media market, as well as the fact that the legislature offers no strict path to become a journalist, e.g. dedicated schools of journalism (Kirchhoff \& Prandner, 2016). The reason for this specific situation is tied to the professionalization process, that happened over the last 70 years and can be roughly divided into three waves. The first phase is tied to the aftermath of World War 2 when the intention was to establish vocational orientated training programs, which failed and thus may be the primary reason why there are no dedicated J-schools today (Hummel et al., 2012, p. 6). The idea of journalism as a vocation founded in talent and calling was strong at this time. It was not until the late seventies - as a consequence of the then newly established press-subsidies-law, which also provides money for journalism education - that both, university level education as well as practice orientated training programs found traction (Hummel et al., 2012, p. 7). This split happened as young journalists were primarily interested in practical training, but not in theoretical backgrounds, which are at the center of the curricula of Austrian universities (Pürer, 1981). The vast majority did not judge university degrees as useful for a career in journalism. The third phase began with the establishment of Universities of Applied Sciences (UAS) in Austria in 1993. Further training programs were created, as the demand from people interested in getting a training in the journalistic craft rose. Despite the 
industry not having the capacity to absorb the high number of graduates, coming from all the different programs that tie to journalism (Dorer et al., 2009; Kirchhoff \& Prandner, 2016, p. 95; similar for UK, compare Frith \& Meech, 2007).

Macro-analytical studies between 2007 and 2011 show that the Austrian journalistpopulation consists of approximately 6.000 professionals (Hummel et al., 2012; Kaltenbrunner et al., 2007). While it has to be noted that macro studies that map the field are missing since 2011, evidence suggests that those numbers have proven to neither decrease nor increase in any significant way (Kirchhoff \& Prandner, 2016). Yet the number of individuals with university degrees in the field continues to rise and currently a third of the professionals finished university level education (ibid.). This makes us go full circle to the quote by Hanusch et al. (2016) that concluded the first part of this paper: Why do students enroll communication studies - by extension journalism studies? Why do they chose the program and do they at all intend to become part of the journalistic profession?

\subsection{Entering the field: In-between expectations and reality}

Studies among students asking for motives for studying journalism or for intentions to work in the field overall identify two main motives: conversion related (e.g. appealing working conditions) and interest related (e.g. pleasure for writing). However, their importance differs according to context (e.g. country) and population (e.g. print vs. broadcast). Hanusch et al. (2016) report that the most dominant motivations for studying journalism are hopes for a varied lifestyle and opportunities to express creativity. Less important are public service ideals and financial concerns. Pjesivac (2017) found that both, intrinsic and extrinsic motivations have a significant impact on the willingness to work in journalism. However, Madison et al. (2017) conclude that among majors in mass communication the perceived ability to satisfy intrinsic needs leads to higher satisfaction with the chosen major. Bjornsen et al. (2007) investigated, beneath motivations for studying journalism, the socio-economic background of becoming journalists over time and what difference Jschools make by shaping becoming journalists. Specific expectations of what makes a good journalist prevail. Those expectations are embedded into the field as both, part of the doxa understood as central believes - and illusio - understood as central reasons - that govern the how and why individuals intend to participate in a given field. Yet those expectations are shaped by the participants within a field, they are also influenced by entities outside the field as people are exposed to different socialization instances (Bourdieu 1998). According to Bourdieu and Wacquant (1996) a field is an agglomeration of relations between positions. Its structures are a result of the distribution of power within the field. Each field follows an own logic and implicitly evolves codes of conducts (doxa). To participate in a field individuals have to posses specific capabilities and be aware of the applicable codes of 
conduct. Individuals decide to participate in a certain field - e.g. journalism and therefore attend a certain education - if they believe they will benefit from participation. This is what Bourdieu calls illusio. It describes the interests as well as meanings and values associated with the field. Participating also means accepting the doxa. Nevertheless participants enter with a certain habitus which is the incorporation of socialization experiences. However, although the habitus is an individual trait it changes over time as individuals interact in certain fields (Bourdieu, 1987). This leads to the following questions (see also figure 1):

What are the motives for entering a training program related to journalism? How are these motives influenced by the socioeconomic background?

How are these motives associated with the intention to work in the field of journalism? How does the institution of training and the progress in study influence this intention?

\section{Methodological design}

The data used for the analysis is based on the national dataset of the "Journalism Students across the Globe”-project (JSAG, 2015), which collected data on Austrian journalism students in 2015 via pen and paper survey at all three Austrian universities that offer communication studies and three universities of applied sciences that offered journalism related programs. The survey included background information on the students, as well as their values, aspirations and attitudes. As there are no programs that lead to the job title of journalist, the field team selected the largest lectures in both Bachelor and Master programs on the topic of journalism at a given semester and distributed the survey directly to the students. Opting out was possible. This can be described as a multi-stage sampling process that was guided by the conscious decision to recruit individuals that have at least somewhat of an interest in journalism. This resulted in a sample size of 352 individuals. While not a random sample, it offers relevant insights into the structure of students and helps identify core issues tied to the field of journalism studies and journalism education. The analyses were calculated via IBM SPSS V24 and AMOS V23.

\subsection{Description of variables}

Table 1 shows the means of the items regarding the motivations of the respondents for entering a program. Most agreeable motivations are having a varied and lively work, being able to be creative and the chance to meet different people. Prospects for a dynamic lifestyle, pleasure of writing and the amount of autonomy one has are important as well. This goes along with findings of Hanusch et al. (2016). Of less importance is the prestige of journalism as a profession, helping the government to achieve its goals and being famous. 
Table 1. Descriptive statistics motivations and component analysis

\begin{tabular}{ccccccc}
\hline Variable & Loadings & Communalities & N & Mean & SD \\
\hline Component 1: political and social agency (Var. explained: 34,8\%; Cronbachs Alpha: 0,890) \\
\hline work for freedom and democracy &, 853 &, 819 & 349 & 2,49 & 1,308 & H \\
fight injustice &, 852 &, 775 & 351 & 2,54 & 1,269 & H \\
hold people in power accountable &, 827 &, 718 & 349 & 2,25 & 1,191 & H \\
help in nation-building &, 753 &, 637 & 351 & 2,69 & 1,227 & H \\
chance to influence public &, 748 &, 589 & 350 & 2,13 & 1,123 & H \\
help government achieve its goals &, 684 &, 478 & 351 & 1,71 & 0,867 & H \\
help people in their everyday life &, 576 &, 396 & 350 & 2,80 & 1,131 & H \\
\hline Component 2: employment driven (Variance explained: 15,1\%; Cronbachs Alpha: $\mathbf{0 , 6 6 6 )}$ & \\
\hline secure job &, 892 &, 820 & 350 & 2,34 & 1,251 & L \\
income &, 829 &, 723 & 348 & 2,85 & 1,172 & L \\
autonomy one has &, 500 &, 467 & 346 & 3,35 & 1,112 & \\
\hline
\end{tabular}

Component 3: social benefits (Variance explained: 9,4\%; Cronbachs Alpha: 0,593)

\begin{tabular}{cccccc}
\hline travel &, 783 &, 663 & 353 & 2,58 & 1,351 \\
meet different people &, 681 &, 495 & 352 & 3,85 & 1,013 \\
dynamic lifestyle &, 660 &, 463 & 350 & 3,42 & 1,104 \\
\hline
\end{tabular}

Component 4: calling/talent (Variance explained: 8,0\%; Cronbachs Alpha: 0,820)

\begin{tabular}{ccccccc}
\hline taltent for &, 868 &, 838 & 350 & 2,56 & 1,246 & H \\
pleasure of writing &, 866 &, 861 & 351 & 3,36 & 1,299 & H
\end{tabular}

Descriptive statistics Motivations (Mean: Scale 1 - 5): low score equals low impact on motivation

H: sig. higher scores from people who aspire to be journalists; L: sig lower scores; sig <= 0,005 / MW-U-Test

Excluded items: varied and lively work $(\mathrm{N}=349 ;$ Mean=4,44;SD=0,747); be able to be creative

$(\mathrm{N}=350 ;$ Mean=4,05;SD=1,013); hold people in power accountable ( $\mathrm{N}=349 ; \mathrm{Mean}=2,25 ; \mathrm{SD}=1,191 ; \mathrm{H})$; prestige of journalism $(\mathrm{N}=352 ;$ Mean=1,89;SD=0,998;H); being famous $(\mathrm{N}=349 ; \mathrm{Mean}=1,53 ; \mathrm{SD}=0,866 ; \mathrm{H})$

On the basis of an exploratory factor-analysis four components were extracted. Component one is named political and social agency as it is associated with items like work for freedom and democracy, fight injustice etc. Component two was deemed to be employment driven, as it includes the aspiration for a secure job and high income. Component three describes 
expected social benefits that go along with working in journalism (e.g. the opportunity to travel). Finally, component four is associated with the idea of journalism as a calling, indicating that the profession and thus the programme just fits the talents of the respondents. As indicators for the socioeconomic background the education of the parents ( $1=$ at least one parent has completed tertiary education $-32,6 \%$; $0=$ no parent with tertiary education) and the economic conditions when growing up (Scale 1 - 5: 1=well below average; $5=$ =well above average) were included in the model. To estimate the effects of the training process the variables university (1=public university $-71 \%$; $0=$ university of applied science) as well as master (1=postgraduate - 15,5\%; $0=$ undergraduate) were included. Control variables are sex ( $1=$ female $-81,4 \%$; $0=$ male) and age in years (Mean: 23,4). Dependant variable is the intention to work in the field (1=journalism - 23,4\%; $0=$ others).

\section{Results}

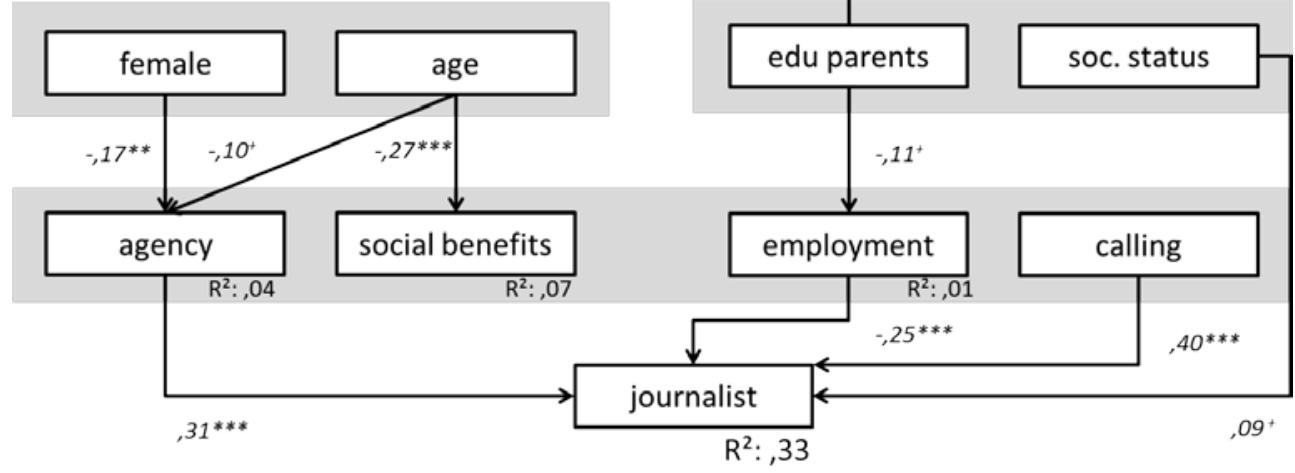

Figure 1. Trimmed model $(+p<0,1 ; * p<0,05 ; * * p<0,01 ; * * * p<0,001)$ arrows indicate direction of influence; Aspiring to be a journalist is the dependent variable for the model $(1=$ yes $/ 0=$ no)

Taking a look at the trimmed path model (figure 1) it becomes obvious that the education of the parents has a significant influence regarding the importance of employment related issues. It also influences whether a program at a public university or a university of applied sciences is chosen. Individuals coming from parents without a university background tend to favor universities of applied sciences as well as regard employment associated gratifications of more importance. Yet the socioeconomic status when growing up 
influences the intention of working in the field of journalism. The better the conditions when growing up are rated the more likely the individuals are to intend to work in journalism. The motives are most strongly tied to the sociodemographic control variables (sex and age). Men are more interested to work on the political and social agenda setting. The older the respondents are the less interested they are to work on those issues and the less important the social benefits going along with the profession are. The intention to work in the field of journalism is dependent on the motives agency, employment and calling. Someone reporting the motive of agency is more likely to intend to work in the field. The same is true for those who think journalism is their calling. Those focusing on employment related issues rather do not intend to work as journalists. Those seem to be individuals interested in the field but well aware of the struggles in the job market. Yet the context of where someone studies and how far he or she has progressed in his or her studies does not make any difference on their aspiration to work as journalists.

\section{Conclusion}

Our results show that the motivation to join the journalistic profession is deeply related to beliefs of individuals. Those who study journalism related subjects at the tertiary educational level have normative aspirations like a political or social agenda and interpret journalism as a calling. Understandably so as those ideas are deeply ingrained into the doxa as well as the illusio of the field (Kirchhoff \& Prandner, 2016). Journalism is framed as a profession that strives to challenge the mighty, where those who think they have the talent to be a wordsmith aim to make their mark, as the term the fourth estate so vividly illustrates (McQuail, 2013) and makes interested individuals endure in a dire job market (Dora et al., 2009). Yet those fundamental underpinnings are not the primary concern for many who study journalism. Those who are focusing on employability are less likely to aspire to be journalists, even if they study a subject with close ties to the field. For educators this heteroginity in higher education has to be seen as challenge, as the field of journalism studies is highly normative and tied to the concept of the fourth estate and civil sphere. The discrepancy between curricular focus and students aspirations makes it necessary to rethink how core concepts of journalism related education can be framed in a broader context. That the education of the parents is a deciding influence on the reasons why someone aspires a profession and how someone choses which university he or she visits matches with former empirical findings. In Austria education is still strongly tied to family background and people from families with lower education are more likely to search for education that brings more tangible results and increases their employability. Even as more employment driven training and education programs are offered, journalism remains a field that is governed by the aspirations and believes of individuals and the illusio individuals bring with themselves. 


\section{References}

Bjornsen, G., Hodven, J. F., \& Ottosen, R. (2007). Journalists in the Making. Findings from a longitudinal study of Norwegian journalism students. Journalism Practice, 1(3). 383403.

Bourdieu, P. (1987). Sozialer Sinn: Kritik der theoretischen Vernunft. Frankfurt: Suhrkamp. Bourdieu, P. (1998). Praktische Vernunft. Zur Theorie des Handelns. Frankfurt: Suhrkamp.

Bourdieu, P., \& Wacquant, L. J. (1996). Die Ziele der reflexiven Soziologie. In P. Bourdieu \& L.J. Wacquant (eds.). Reflexive Anthropologie (pp. 95 - 249). Frankfurt: Suhrkamp.

Dorer, J., Götzenbrucker, G., \& Hummel, R. (2009). The Austrian journalism education landscape. In G.Tetzis (ed.). European Journalism Education (pp. 1296-1550). Chicago: Universtiy of Chicago Press.

Evetts, J. (2011). A new professionalism? Challenges and opportunities. Current Sociology, 59, 406-422.

Friedson, E. (2001). Professionalism. The Third Logic: On the practice of knowledge. Chicago: University of Chicago Press.

Frith, S. \& Meech, P. (2007). Becoming a journalist. Journalism education and journalism culture. Journalism, 8(2), 137-164.

Hanusch, F., Clifford, K., Davies, K., Englisch, P, Fulton, J., Lindgren, M., O’Donnell, P., Price, J., Richards, I., \& Zion, L. (2016). For the lifestyle and a love of creativity: Australian students' motivations for studying journalism. Media International Australia, 160(1). 101-113.

Hummel, R., Kirchoff, S., \& Prandner, D. (2012). Journalismus im Wandel (Forschungsbericht für die RTR). University of Salzburg.

JSAG (2015). Journalism Students Across the Globe. Retrieved from http://www.jstudentsproject.org/

Kaltenbrunner, A., Karmasin, M., Kraus, D., \& Zimmermann, A. (2007). Der JournalistenReport. Vienna: Facultas.WUV.

Kirchhoff, S., \& Prandner, D. (2016). Bausteine des journalistischen Selbstbilds. In Medien-Arbeit im Wandel (pp. 93-114). Wiesbaden: Springer VS.

Madison, E., Hopp, T., Santana, A. D., \& Stansberry, K. (2017). A Motivational Perspective on Mass Communication Students' Satisfaction With Their Major: Investigating Antecedents and Consequences. Journalism \& Mass Communication Educator, D.O.I.: 1077695816687408.

McQuail, D. (2013). Journalism and society. London: Sage.

Pjesivac, I. (2016). What moves young people to journalism in a transitional country? Intrinsic and extrinsic motivations for working in journalism in Serbia. Journalism, D.O.I.: 1464884917738428.

Pürer, H. (1981). Journalistenausbildung im Urteil von Presse Entscheidern. Ergebnisse einer Umfrage des „Kuratorium für Journalistenausbildung“. Medien Journal, 7(4), 915. 